\title{
21
}

\section{FEDERALISM UNDER PRESSURE}

\author{
Federal 'health' factors and \\ 'co-morbidities'1
}

\author{
Nico Steytler
}

\subsection{Introduction}

The Covid-19 pandemic has been a 'focusing event' (Béland et al. 2020) for federalism like no other, placing it under the microscope and giving rise to the three questions set out in the introduction of this book. Each gives rise to a number of subquestions. First, how did federal systems respond to the pandemic during the first critical period of 2020, when quick, concerted, and effective action was necessary to limit the virus and its dire socio-economic consequences? What were the modalities of action? How did they impact on the constitutional distribution of powers - did they lead to an increase in centralisation or decentralisation? Did intergovernmental relations (IGR), the lifeblood of federal systems, work efficiently or at all? What happened to intergovernmental fiscal relations?

The second question is more evaluative: How well (or badly) did federal systems, which by nature involve dispersed decision-making, fare in combating the pandemic? How did federalism perform as a system of governance in the modern age when confronted unexpectedly with such a massive global crisis? Although most federations saw a trend towards centralisation, none of them lost their federal character entirely to become unitary states. The question then is whether the fundamental characteristics that Ronald Watts regarded as essential to the success of federalism were also relevant in combating the pandemic effectively. The 'federal success factors' Watts posits are

- a strong disposition to democratic procedures, which presumes the voluntary consent of citizens in the constituent units;

- multiple centres of political decision-making that give expression to the principle of non-centralisation;

- $\quad$ open political bargaining as a dominant means of reaching decisions; and 
- respect for constitutionalism and the rule of law, given that each order of government derives its authority from the constitution (Watts 2011: 16-17).

Conversely, did those federations that showed failures in respect of one or more of these characteristics perform worse in health and well-being outcomes than would have been the case otherwise? Were these federal 'health' factors relevant under an emergency situation and should the list be complemented?

The third question is this: Where changes in federal dynamics did occur due to Covid-19 - a movement towards decentralisation or centralisation - are they likely to have long-term consequences for that federal system? Will the impact of Covid-19 reverberate long after the health and economic consequences are more or less under control? Did the pandemic open or close a 'policy window' for more fundamental changes?

The 18 country studies show that during 2020 most of the federal systems under review became more centralised in response to the pandemic, but not uniformly or continuously so. IGR was often inadequate or non-existent, in the process fortifying centralised rule; the increased dependence of subnational governments on federal transfers also had a centralising effect. I conclude, furthermore, that some federal systems were resilient enough to deal effectively with the pandemic. In many if not most cases, however, the success factors, if at all present, came under pressure with predictable results. What contributing authors described as failures in their respective federal systems, led to poor outcomes both in respect of effective governance and lives lost as well as hardships incurred. These failures, mostly proceeding from pre-existing problems, can be labelled as 'federal comorbidities': their presence in the federal body politic made the system less able to face the Covid-19 challenge successfully. In addition to the four characteristics mentioned by Watts, the capability of governments at all levels should join the list. Finally, although it is still too early to tell, Covid-19 might be a catalyst in some countries for greater decentralisation, in particular in the field of fiscal federalism.

Due to space constraints, these concluding remarks do not do justice to the richness of the country studies; the remarks are, inevitably, prone to generalisation that does not fit all the countries. Given that all the countries were subjected to the same coronavirus at the same time, and exposed to the same World Health Organization (WHO) information, world media coverage, and the scientific community, the responses were on the whole noticeably similar. However, drilling down to the detail, it is clear that the very characteristics (geographical, demographical, economic, political, and governmental) which made each country a unique federation in the first place also shaped the individual responses to Covid-19.

\subsection{The relevance of contextual factors}

As Cheryl Saunders notes in Chapter 20, geophysical characteristics, economic development, the form and operation of government, and the multifaceted framework for federalism all had a significant influence on the conduct of IGR. 
In this section, I sketch out how the other aspects of federalism may have been influenced by the same contextual factors.

First, geographical size mattered. Seven of the eight largest countries in the world are federations: Russia, Canada, the United States (US), Brazil, Australia, India, and Argentina. In such vast territories, infection rates varied from region to region, which allowed for differentiation in government responses. From the outset, emergency powers were delegated to Russia's 85 constituent units to deal with local conditions; the eastern Canadian provinces could effectively selfisolate themselves as the 'Atlantic bubble', as did the state of Western Australia in closing its borders to the rest of the country. On the other side of the spectrum, in smaller federations, with high interconnectivity (e.g. in Switzerland and Belgium) the prospect of self-isolation of constituent units was limited.

Moreover, with seven of the 10 most populous countries in the world being federations (India, the US, Pakistan, Brazil, Nigeria, Russia, and Mexico), anti-pandemic measures had to be of enormous magnitude, requiring plentiful resources. With diversity along racial, ethnic, linguistic, and religious lines lying at the root of the federal nature of 13 of the federations presented in this book, the pandemic brought divergent communities closer together in some instances but in others drove them further apart. On the positive side, to everyone's surprise, the Catalonian government worked remarkably well with the Spanish government, and the highly divided Belgium saw its two linguistic communities cooperating at the centre as never before. On the negative side, the pandemic was used to deepen cleavages in India (the promotion of anti-Muslim sentiment), in Nigeria, and, most tragically of all, in Ethiopia, where a political dispute between the centre and the ethnic region of Tigray degenerated into civil war. Further, the marginalisation of voiceless indigenous communities in Brazil and Mexico was exacerbated. Poverty and unemployment among South Africa's majority black population also increased, deepening inequality.

The high levels of urbanisation in most federations - as well as the large, densely populated cities in countries with low levels of it, such as India and the African federations - facilitated community infections. It was only when the 'traffic light' regulatory system was introduced - that of differentiated unlocking and re-locking during the second wave of infection - that low-infected rural communities could become less subject to the overbroad national measures designed with urban areas in mind.

Economically, the selected federations represent most categories of income levels. In terms of the World Bank classification (2020), 10 are high-income countries; Argentina, Brazil, Mexico, Russia, and South Africa are upper-middle income; India and Nigeria lower-middle income; and Ethiopia low income. These classifications, of course, hide inequality levels within federations. It is particularly the upper-middle-income countries where inequality is most pronounced: Brazil, Mexico, Argentina, and South Africa (by far the most). It is in these low- and middle-income countries that public health-care systems are underfunded, less testing is conducted, less infections are recorded, and poor medical care is provided. 
When it comes to governance, six of the 18 federations have a presidential system, while the rest have some form of parliamentary governance. Populist personalities seemed to thrive in presidential systems - the 'denialist' presidents of the US, Brazil, and Mexico, for example. The parliamentary systems, on the other hand, showed a strong tendency towards cooperation and coordination at the national level as well as with the states (Australia, Belgium, Canada, Germany, Spain, Switzerland, the United Kingdom (UK)). But parliamentary systems also gave rise to dominant federal executives averse to cooperative governance (Austria, India, South Africa, and, as the worst case, Ethiopia). In both systems, authoritarian tendencies were noted: in Russia, Argentina, and Nigeria (presidential) and India and Ethiopia (parliamentary).

Among the more dynamic factors that influenced the course of government action was the nature of the party system, and the selected federations reflect a wide variety. A few countries are dominated by a single party operating at federal and state levels and centrist in orientation (cf. Detterbeck and Hepburn 2010). The primary examples are Russia, where President Putin's United Russia controls the centre and all but nine of the 85 constituent units; India's Bharatiya Janata Party, which controls Parliament and 21 of the 28 states; Ethiopia's Prosperity Party, with near-total control of the federal legislature and nine of the 10 regional states; and South Africa's African National Congress, which controls the national Parliament and eight of the nine provinces. Although the ruling party in Argentina does not dominate Congress, opposition parties govern in only three of the 23 provinces and the Autonomous City of Buenos Aires. Such dominance enabled ruling parties to use the party hierarchy as the primary IGR instrument.

On the other side of the spectrum are more competitive party politics, which in parliamentary systems have given rise to 'grand coalitions' in Germany or even to minority governments in Belgium, Canada, Italy, and Spain. Nonentrenched majority parties with active opposition are found in the UK and Australia. None of the ruling parties of the British devolved units is linked to the Conservative Party in Westminster, while in Australia there is an even split, with the opposition Labour Party governing three of the six states and two territories. In Canada, the Liberal Party governs at the centre, while its very loosely connected liberal counter-parts only led in two of the ten provinces. In the absence of a hegemonic party, cooperation at the national level and vertically with states was the order of the day.

In presidential systems with competitive party politics, for example, the US, Mexico, and Nigeria, presidential and federal legislative results were also reflected in subnational governments: in the US 26 states had Republican governors while 24 states had Democrats. In Mexico, the split between the ruling party and opposition parties was even at state level. In Brazil, President Bolsonaro governs without party affiliation and a stable support in Congress and the majority of the state governors have no truck with him. In these federations, the common theme is that political ideology and partisanship were the driving force behind 
decision-making, as was only too evident in the fact that distributions of funds were biased against opposition-held states.

\subsection{The federal constitutional and legislative framework}

The pandemic, by its very nature, impacted on numerous aspects of governance, ranging from international relations, in which nations were kept apart by border closures, to local government, where the effort was to keep individuals apart through social distancing. Nor were response measures to Covid-19 restricted to health care or disaster management: they also affected competences relating to education, social protection, social welfare, and the economy - all of which are particularly germane to federalism, given that the starting-point in a federation is the constitutional allocation of powers (with its possible suspension during a state of emergency being the exception).

\subsubsection{Constitutional allocation of powers}

The usual constitutional devices of allocating powers in federal systems also apply to health care and disaster management and range from the exclusivity of dualist approaches to the intermingling of powers in integrative systems (Poirier and Saunders 2015). In a significant number of federations, health care is predominantly a state function, as in Australia, Belgium, Canada, Nigeria, Switzerland, the UK, and the US. Such allocations are seldom watertight, though, resulting in varying forms and degrees of concurrency. In particular, federal governments usually retain influence through the power of the purse in countries where they enjoy superior taxing powers. In the majority of countries, the two areas are formally concurrent or (de facto) shared functions in one or other form (see Steytler 2017), as is the case in Brazil, Ethiopia India, Italy, Mexico, Russia, South Africa, and Spain. The federal government usually develops general frameworks and policy guidance, while the state governments provide the health services, resulting in intended or de facto executive federalism (Argentina, Austria, Ethiopia, Germany, South Africa).

With regard to these two main functions, local government plays only a peripheral constitutional role. In half of the federations, local government is a competence of the states and thus derives its mandate from state legislation. Although half of the federations constitutionally recognise the existence of local government as an order of government, very few attribute specific functions to it. Argentina, Brazil, and South Africa are unique in listing specific powers, including 'municipal health care', that local authorities exercise in conjunction with the other orders of government. In the rest of the countries, local government performs a range of statutory municipal functions, the most important areas of responsibility during a pandemic being water, sanitation, waste management, and control of public spaces.

A strong common thread is that health care and disaster management, as well as the other affected areas such as education and social welfare, are every level 
of government's business. All powers are to some degree concurrent - and are divided not only between two, but three or four tiers (the international one included) - circumstances which called out for coordination and cooperation in the face of a common enemy.

\subsubsection{Emergency declarations}

The constitutional division of powers (along with basic human rights) could be upset by a declaration of a state of emergency, which empowers a federal government to intrude on subnational constitutional space. In most countries, only the federal government may impose a state of emergency, usually entailing legislative approval and other checks and balances; in a few countries, states may also declare states of emergency in terms of their own constitutions (the US, Argentina, and Ethiopia).

A similar empowerment of federal and state executives can be obtained in most countries by using ordinary legislation dealing with disaster management and/or public health emergencies, a process usually not subject to significant legislative oversight. States in Australia, Brazil, Canada, and Switzerland have co-equal powers with the federal government to declare a state of disaster. Often a federal declaration of disaster or health emergency also provides a framework in terms of which subnational governments can make their own disaster declarations because of the anticipated localised impact of a disaster or epidemic (Argentina, Italy, Nigeria, Russia).

Where federal legislation is couched with reference to disaster management, it usually includes the broad category of 'epidemics'. Legislation may also refer specifically to 'epidemic and health disasters'. In their responses to Covid-19, the federal governments of India and Nigeria relied on epidemic legislation dating back to the colonial area (Indian Epidemic Diseases Act of 1897; Nigerian Quarantine Act of 1926), which, of course, demonstrated scant regard for the federal system that had emerged subsequently.

\subsection{Preparedness for a national disaster: The institutional framework}

Preparedness for a pandemic requires nationwide federal institutions, structures, and processes which can act promptly, concertedly, and effectively. However, given that health care and disaster management are the responsibilities mainly of subnational government (which is thus where the capability lies, or should lie), the question is whether subnational governments participate in these national institutions.

All the federations under review had legal frameworks in place to deal with pandemics. Only a minority - Australia and the UK, for example - had to update their health epidemic laws during the pandemic for being outdated and not providing the federal executive with sufficient powers. Furthermore, all the federal 
governments (except Switzerland) have a department of health (and sometimes one for disaster management as well), in addition to which most have national scientific bodies advising the government. Many such federal structures do not, however, provide for subnational participation (Austria (initially), Ethiopia, Italy, Russia, Spain). The lack of coordination between levels of government became painfully evident when problems with data collection came to the fore, as happened in Italy, Spain, and Switzerland, for example; there were no coordinated systems enabling the methodical collection of data, a fact which hampered getting an accurate picture of the pandemic necessary for planning.

Australia and Canada seem to be exceptions. Well-prepared nationwide institutions were in existence and providing for subnational participation, all of which seeming to have proven effective when Covid-19 struck. Although the US had well-established federal institutions and plans for epidemics (with good IGR cooperation from state administrations), the budgets of these institutions had been reduced over the years, rendering their emergency plans less than effective.

In countries where there are national institutions and processes with an IGR dimension, these remained largely inoperative. In Switzerland, the Intercantonal Conference of Health Ministers made way for a number of ad hoc taskforces. In South Africa, the national advisory Intergovernmental Committee on Disaster Management includes provincial representation but never convened; decisions were instead made by a national cabinet committee called the National Coronavirus Command Council.

Overall, most federations were unprepared for the unprecedented magnitude, swiftness of spread, and deadly consequences of Covid-19. Plans had focused mostly on past national crises such as terrorism and the 2008/2009 global financial crisis (true of the European Union (EU) in particular). The lack of preparedness was compounded in low- to middle-income countries by chronically underfunded public health-care systems.

\subsection{Rolling out of measures to contain the pandemic}

Given the unpreparedness of most federations, Covid-19 required urgent action from federal and state governments alike where they shared responsibility for health care and disaster management. Cities that experienced the first signs of the pandemic were also called to intervene.

In the face of the approaching pandemic, the body politic on the whole showed solidarity, providing a conducive space for prompt federal action. The first response of political parties across the political spectrum was to rally together against the common threat and express support for the first lockdown steps taken by the federal government. There were exceptions: in Nigeria, the enmity following the 2019 election percolated through to President Buhari's declaration of a health emergency, which the main opposition party opposed; in the face of denialist presidents, political solidarity in Brazil and Mexico was also a bridge too far. 
Bonhomie towards the national lead soon evaporated in the glare of partypolitical interests. In the US, while the first relief bills were adopted on 11 March by huge bipartisan majorities, by June gridlock settled in between the Democratic-controlled House of Representatives and the Republican-controlled Senate. In other federations, disputes arose about the pace of loosening restrictions; left-of-centre parties argued on the side of health preservation, while those on the right-of-centre were more concerned with job losses and the economy.

Unheard in the political cauldron of mainstream politics were the voices of minority and indigenous groups. They remained as voiceless and powerless as before, although they were more prone, due to a variety of factors, to succumbing to the virus. The situation of Brazil's indigenous communities in Amazonia, falling within the jurisdiction of the federal government, became much worse under President Jair Bolsanaro. Mexico's indigenous communities resorted to self-help by closing off their communities and taking their plight to the courts, where they challenged the distribution of information and health resources. In Canada a number of vulnerable indigenous nations erected borders around their communities, with the tacit approval of all orders of government.

\subsubsection{Taking the initiative}

With Covid-19 beginning to spread across the globe and the WHO declaring it a 'public health emergency of international concern' on 30 January 2020 and a pandemic on 11 March, federal rather than subnational governments made the first move. Most exercised their international relations competence by closing international borders to travellers from China and gradually also to those from other 'hotspot' countries. These preventative measures were usually too late, though: the virus rapidly gained footholds in cities which are globally well connected.

Facing at first a highly localised epidemic, states and cities directly affected by the virus took action to contain community infection through various lockdown measures (including internal border closures), while the federal governments looked upon from afar. In particular, it was the major cities, linked internationally and experiencing the flood of first cases, that acted first: Milan, Moscow, San Francisco, New York, Sao Paulo. The city state of Lagos took the first steps as it, with its busy international airport, was the epicentre of the pandemic in Nigeria.

Preventative measures were not always uppermost in the minds of affected cities or towns, as the Austrian village of Ischgl illustrates. Ischgl is dependent on the ski-tourism that attracts visitors from around the world. When returning tourists fell ill, the alarm bells rang from Iceland and Germany that it was a super-spreader location, but the responsible district administration vacillated about placing Ischgl under quarantine - a quarter of its jobs were tied to the hospitality sector. It thus took the federal government to cordon the village off.

Early intervention by states and cities, typically ones under opposition-party control, were spurred on by the denialist, anti-science attitudes of the presidents 
of the US, Brazil, and Mexico. But states could also play partisan politics: the early declaration of emergency by the Tigray regional government had little to do with the pandemic and far more with affirming its autonomous political status.

In Germany, local governments, acting under the advice of the Länder, were the first to impose lockdown measures: Covid-19 infections were perceived as a localised problem that could be solved locally. However, as soon as it became apparent that the pandemic was widespread, particularly after holidaymakers returned from their ski-holidays in Ischgl, the federal government and Länder stepped in to declare a national lockdown. The federal principle of subsidiarity was in full operation: where a local authority could not perform a function effectively, that function moved to the next level of government.

The time delay between states and cities taking the initiative with lockdown measures and the federal government's acting was at most a week or two. The significance of these initiatives is not only that states or cities could act upon the competences they shared with the centre, but that, by doing so with public approval, they goaded the federal government into action it might not otherwise have taken as quickly as it did.

In a few countries, the federal government was the only player from the start, having absorbed subnational powers and delegated mere implementation duties to subnational governments (Italy, Spain, Austria, South Africa). In contrast, in Australia, Belgium, and the UK joint decision-making took place between the federal and state governments in which responsibilities were allocated in a coordinated manner. In Canada, the provinces took the lead and remained the dominant players, albeit working closely with the federal government from the outset.

\subsubsection{Federal action}

Covid-19 required prompt, nationwide action. As noted, federal governments intervened early with the gradual closure of international borders to curb infections coming from abroad. More problematic was getting to grips with community infections, where countermeasures fell into either the exclusive or concurrent domain of subnational governments.

\subsubsection{Expansion of powers and declaration of emergencies or disasters}

At the outbreak of the pandemic, federal governments had a range of legal instruments at their disposal to upset the constitutional allocation of powers by centralising them. In the event, with two exceptions (Argentina and Ethiopia), the federations under review did not declare a general state of emergency, which would have triggered formal legislative checks and balances. In the case of Argentina, it had already been under its frequently used mode of governance - emergency rule - since December 2019 because of an economic 
crisis; the Ethiopian emergency declaration had more to do with political instability than confronting Covid-19. Instead, most federal governments used ordinary legislation to empower themselves with delegated law-making authority, placing themselves largely beyond the scrutiny of legislatures.

In a small minority of federations, no federal emergency of whatsoever kind was called. The Canadian federal government let the provincial declarations of health emergency take the lead, for among other reasons that they were sufficiently effective for the job at hand. In Australia, the national Biosecurity Act of 2015 had already shifted powers to the centre - so closely as to being nearly constitutionally impermissible - and thus obviated the need to do it during the pandemic. Moreover, the Commonwealth government used its powers under the Act sparingly, allowing the states to exercise their competencies under this Act within a consensus framework.

Declarations of health emergencies rewrote the rule book, conferring powers over health care and related areas to the federal government. Even in the predominantly dualist federation of Belgium, the federal declaration (made with the support of the communities) shifted health care to the federal level. In more centralised federations where health care and related areas are concurrent functions, the declarations simply asserted the primacy of the federal government over state decision-making, reducing states to implementers of national rules and policies. In Spain, for example, the centre's declaration of a 'state of alert' resulted in its assuming all powers over health care, which over time had been devolved to the Autonomous Communities.

An important consequence of some national declarations of a health emergency was that they also devolved emergency powers to states, thereby enhancing state executives' regulatory powers. Russia is an example in this regard.

\subsubsection{Substantive measures}

With or without enhanced powers from declaration of health emergencies, the federal government could perform a number of unique functions.

First, in the face of an unpredictable but deadly pandemic, national leadership sought to assuage citizens' anxieties. As a rule, heads of governments were the principal communicators about the pandemic's status and the various measures taken. Often, they were joined by the leaders of subnational governments to show joined-up government at work. In stark contrast were the presidents of the US, Mexico, and Brazil, whose non-scientific rhetoric conveyed a confusing message to the public. President Trump, for one, purposefully called upon citizens not to obey states' stay-at-home orders.

Secondly, where uniformity of measures was called for, federal governments provided that. In small- and medium-size federations with mobile populations, uniform lockdown measures gained popular acceptance.

Thirdly, because of the federal governments' superior access to resources, revenue and borrowing, they could address the harsh consequences that lockdown 
regimes created. Where social protection in its various forms was a federal responsibility, federal governments could provide individuals and families with support through grants, top-ups and other means of assistance. Federal governments could assist ailing businesses and try to stimulate the economy back to life on a scale well beyond the reach of subnational governments. They could also support subnational governments with funds to execute the extra burdens they carried. Most federal governments also deployed the military to provide health resources (particularly medical personnel and the construction of field hospitals) and enforce lockdown regulations.

However, the limits of federal action were also manifest. First, although the need for centralisation of powers was accepted in many countries, a major unforeseen problem emerged: the federal government lacked capability. Because health care was the predominant or main domain of the subnational governments in Italy, Spain, and Switzerland, the federal government, on assuming that mandate, plainly lacked the capacity (skills and resources) to act swiftly and effectively. Secondly, uniform measures often had disproportionate negative effects. For example, in Switzerland, the Federal Council directed all cantons that hospitals should no longer do non-essential procedures and prepare only for Covid patients. However, because infection rates varied considerably between cantons, some cantonal hospitals ran out of work and income when Covid patients did not turn up in the droves that had been anticipated.

The value of federal Covid-related action was compromised even further by pre-existing political pathologies. First, entrenched cultures of corruption were simply aggravated by the pandemic. In our sample, a significant number of federations have a serious corruption problem: according to the Transparency International Corruption Perception Index of 2020, in descending rank order in the world were South Africa (69), Argentina (78), India (86), Ethiopia (94), Brazil (94), Mexico (124), Russia (129), and Nigeria (149) (Transparency International 2020; Vrushi and Kukutschaka 2021). Although corruption is pervasive at all levels of government, at the federal level it had the greatest financial and moral impact.

The increase in corruption was due to huge amounts of money becoming available overnight for the purchase of materials and services, the relaxing of procurement rules for the sake of urgency, and the fact that the usual countercorruption measures, such as vigilant parliaments, went to sleep. Instead of the nation standing together, the few fed off its misery as scarce funds to combat the virus disappeared into the pockets of government officials and their cronies. Increased corruption was reported in South Africa, and Nigeria.

Secondly, some federal governments used both their extended powers and the centralised ethos the pandemic created to advance their own political agendas. As the old adage goes, 'Never waste a good crisis.' In Argentina, President Alberto Ángel Fernández sought the power to change the national budget unilaterally; India's Prime Minister Narendra Modi pushed through a parliamentary bill advancing the centralisation of agriculture and education; Russia's President 
Vladimir Putin used the pandemic in his campaign for constitutional amendment, which, inter alia, extended the presidential term of office (his own, that is); and, as noted, the postponement of Ethiopian elections scheduled for August 2020 had more to do with avoiding an election than countering a low level of Covid-19 infection.

\subsubsection{Accountability}

The drift towards the increase of executive powers vis-à-vis the legislature is evident in both presidential and parliamentary systems. In the former, presidents ruled by decrees and orders that fell outside the legislatures' legislative domain and the term 'hyper-presidentialism' has been applied to Russia and Argentina. In parliamentary systems, parliaments often gave prime ministers a free pass and played a muted role.

After initially suspending their activities out of compliance with social distancing measures, legislatures limped back into full or partial operation by holding their sessions online. The general complaint is that parliaments were marginalised, more often than not through actions of 'self-disempowerment'. When called upon to pass enabling legislation and authorise support packages, they acted with astounding speed and expeditiousness. Within a single day Sunday 15 March 2020 - the Austrian parliament passed the Covid-19 Measures Act, the President signed it into law, and it was promulgated. Where there was insufficient debate and scrutiny, the legislature became a mere rubber stamp.

The usual parliamentary subnational check and balance on a federal executive is through the second house that represents subnational interests. The usefulness of such a house was exemplified by the German Bundesrat, which approved both the declaration of a health emergency and Covid-related bills. Conversely, subnational interests could be replaced by partisan political concerns, the prime example being the US Senate.

In the absence of vigorous parliaments holding executives to account, courts became the next port of call for aggrieved parties, although the speed with which regulations were changed, renewed, or repealed often made slow-moving litigation unhelpful. The primary litigators were individuals, citizens groups, or commercial enterprises whose interests (and rights) may have been compromised. There were only a few cases of intergovernmental disputes, because, as Saunders points out in Chapter 20, in some federations governments were subject to the cooperative government duty to avoid litigation or just avoided turf wars.

When confronted with challenges, the courts by and large displayed their customary deferential attitude (cf Aroney and Kincaid 2017): they were not willing to second-guess the federal government's reaction to a deadly and unprecedented disease. There were a few notable exceptions. First, in the context of Brazil's president, the Supreme Court came down unambiguously on the side of the states when it affirmed the latter's power to declare states of health emergencies in contravention of the president's express order to the contrary. Secondly, 
the Austrian Constitutional Court played a vital role in asserting that differentiated measures are important in avoiding unacceptably disproportionate outcomes, which prompted the federal government to be more differentiated in its approach.

\subsubsection{State action}

As noted, the key policy areas affected by Covid-19, among them health care and disaster management, fell under the states' exclusive or concurrent powers. However, in a significant number of countries this constitutional dispensation was disrupted by federal declarations of health emergencies in which states became implementers rather than policy-makers. In other countries where such declarations were either not possible or did not occur, states continued as before. Whatever the applicable regimen, states in some countries improved their status by dint of their performance in dealing with Covid-19. Managing the pandemic enhanced the profile of the UK's devolved units as no other event has done before; the voices of Mexico's states were heard clearly, while in Spain the Autonomous Communities and central government moved towards collaboration they called 'co-governance'.

\subsubsection{Powers of engagement}

As noted, in a limited number of decentralised federations, states could, and did, declare their own health emergencies or disasters, independent of the federal government, thereby extending their executive powers. In the dualist federations of the US, Canada, Australia, states declared such emergencies; the federal governments in Canada and Australia specifically refrained from doing so. In Brazil, state governments had to approach the Supreme Court to assert this right. In the previously highly centrist Ethiopian federation, the breakaway of the Tigray People's Liberation Front from the ruling party resulted in the Tigray regional government's declaring a state of emergency two weeks before a national declaration, again, as mentioned, not so much because of Covid-19 but to assert its autonomy.

In a number of federations, the federal governments, acting upon their own emergency powers, delegated similar powers to state executives (Italy, Mexico, Russia). Russia provides an important example. Its 85 constituent units have limited exclusive powers and joint jurisdiction over health care, but through the federal declaration of a 'heightened state of preparedness', they were delegated the mandate for health care, and thus also burdened with tough choices between pursuing health measures or opening up the economy. With this delegation, the federal government sought not only to enable a diversity better suiting Russia's vast heterogeneity, but also to minimise its own political responsibility by allowing greater scope for localised crisis management and blame. Putin and his ruling party nevertheless remained firmly in control of the constituent units through informal IGR arrangements. 
In terms of the national declarations of health emergencies, states in centralised federations were assigned primarily implementation roles (Ethiopia, India, Italy, Nigeria, South Africa, Spain). However, the same also happened in decentralised ones as a result of states' participation in making the federal declarations (Belgium, Germany).

Getting into lockdown proved to be the easy part; easing the restrictions later on was far more difficult and controversial. With the heavy social and economic costs of the lockdowns becoming increasingly apparent, reopening economies and reviving social mobility brought states back into the decision-making loop. The common tool used across the world was the 'traffic light' system: the coding of the levels of infections according to locality, which allowed for a differentiated approach to unlocking and re-locking. Federations had the great advantage that localities had actors in place able to implement (or fine tune) the traffic light system.

The same system prevailed with the rise of the second wave of infections that began in Europe in the autumn and a month or two later elsewhere. In Germany, the Länder were given the power to impose new restrictions, but when they did so hesitantly, the Bund again ordered a national lockdown. The Swiss cantons' reluctance to take responsibility for the lockdown, which the Federal Council was eager to pass on to them, springs from a different, federal, source. In terms of their system of equivalence, the financial responsibility lies where the power is exercised; as the cantons were not eager to shoulder this financial burden, a hiatus in governance ensued during this critical stage of the battle against Covid-19.

\subsubsection{Substance of engagement}

The substance of the engagement with the pandemic was, at least at the initial stages, about providing health care for the ill and seeking to prevent community infection through lockdown or stay-at-home orders. As implementers of national policies and law, the states' discretion was limited, but some excelled in putting up field hospitals, developing tracing apps, and so forth. Some Nigerian states, mostly opposition-held, performed small acts of defiance by implementing lockdown regulations late or reluctantly where they deemed them unreasonable.

Some states also sought isolation through the constitutionally suspect measure of unilateral closure of internal borders (Argentina, Australia, Brazil, Canada, Mexico). Although the Mexican federal government contested such 'unconstitutional' closure, it tolerated the action by some states. In Argentina, citizens successfully contested a number of state border closures. Australia's High Court, by contrast, rejected a challenge to Western Australia's border closure that was made on the ground that the latter was contrary to the constitutional provision that interstate commerce and movement must be 'absolutely free' (Australian Constitution, section 52), holding that the restriction formed part of an overall federal plan of action. In Canada, few challenged the decision and a sole court case dismissed the argument of unconstitutionality of provincial border closings. 
Ameliorating the plight of people and businesses impacted on by lockdown was mostly beyond states' financial wherewithal, a reality that underlined their dependence on the federal purse. Where social protection had been the states' responsibility before the pandemic, they continued to serve that function (Canada, Australia). Where states had policy discretion, the case studies revealed that the political leanings of the political party in control of a state were often determinative. In the US, the presence of a political 'trifecta' - in which the governor and the two houses of the state legislature were from the same party - had predictable outcomes: the 'trifecta' Republican states preferred limited restrictions and opening the economy, while the 'trifecta' Democratic states opted for stricter health measures. Policy differences could even creep into the same party, in this case driven by personalities. In Germany, the rivalry between two Länder's first ministers vying to succeed Angela Merkel as the next leader of the CDU/CSU resulted in their respective Länder adopting differing Covid-19 policies in order to distinguish the two contenders from each other.

More pervasive than the few cases of incapacity at federal level were incapable subnational states that could not meet their responsibilities. Some South African provinces were incapable of providing effective health care. Similar situations prevailed in other low- to middle-income countries due to chronic under-investment in health care, as, for example, in India. In countries with a corruption problem, its manifestation at state level was sometimes worse than at federal level, given that in far-flung states their finances fell outside of the scrutiny of a watchful media.

\subsubsection{Accountability}

As occurred with the federal executive, power came to be concentrated in state executives, whether in terms of their own or federal declarations of health emergency. Inasmuch as Argentina's federal government is hyper-presidential in style, the same is true of its state governments. Where the pattern was of power concentration in the executive before the pandemic (as in Nigerian states), it was aggravated by the pandemic response. The accountability picture thus differed little from that at federal level. No heightened level of legislative scrutiny was reported: the usual story was that the state legislature, like its federal counterpart, would be suspended and slowly re-emerge transformed into an entity conducting virtual or semi-virtual meetings.

In the more centralised federations, the possibility of federal supervision loomed large: wayward actions could be swiftly countered. Although in some federations differences were tolerated (Mexico), instances of federal supervision occurred. In Russia, a strong party hierarchy enabled President Putin to exercise strict control over the constituent units, with a number of governors resigning after being criticised by a federal agency for the inadequacy of their measures. Putin also dismissed a governor in whom he lost confidence. In South Africa, a country also operating under a hegemonic party, the national minister of health 
criticised the poor performance of one of his provincial counterparts, which eventually led to her dismissal from the provincial executive committee.

In contrast to their deferential review of federal measures, the courts might have been slightly more amenable to keeping state governors in line - for two possible reasons. First, states were occasionally egregious in their lockdown measures, as for example when imposing border restrictions beyond their competences. Secondly, whereas courts might be reluctant to upset the apple-cart of federal disaster management and cause unforeseen nationwide consequences, that concern is not present at state level: any consequences are localised. Although further research is necessary, court decisions on the whole seemed to run against state executives in Germany, India, Italy, and Spain. At the same time, decisions favourable to states were seen in Argentina, Australia, Brazil, Canada, Mexico, and the US.

\subsubsection{Local government action}

Local government, although not constitutionally recognised in most federations, asserted its presence during the pandemic as a valuable order of government. The role it played was strongly influenced by its size and nature in a country; its constitutional status, precarious as it was, proved to be of less importance. Most of the federations under review have a large number of local authorities, running into the thousands, most with very small populations. At the same time they have large, globally connected urban municipalities with considerable resources it was these that typically experienced the early stranglehold of the virus and which provided curative as well as preventative health measures (San Francisco, New York City, and Sao Paulo, for example). The role of the myriad small local authorities should not be overlooked, however, since apart from carrying out their usual functions, they provided support for the most vulnerable in their communities.

\subsubsection{Powers of engagement}

Local government responsibilities flowed mainly from state law, but that was altered in a few instances by federal emergency rule. For example, in Italy, the local government's health powers were centralised. New mandates were also imposed by the federal and/or state governments dealing with preventative health care and ameliorating the plight of the most vulnerable.

When the 'traffic light' system of differential application of lockdown rules was introduced, local authorities formed the base unit of measurement and were sometimes delegated the power to switch the lights up or down. So, for example, local government came to the fore in Belgium during the second wave: the federal government, facing a population that had become Covid-weary, devolved greater powers to mayors to decide on restrictive measures, including the power to target such measures at municipal 'hotspots'. In contrast, when South Africa began to implement a differentiated 'traffic light' system, it remained 
the prerogative of the national government to impose stricter lockdown provisions in 'hotspot' municipalities. A similar position in the UK raised the ire of city mayors in England. In Australia, when a state-wide blanket lockdown was imposed during the second wave, municipalities in the state of Victoria argued unsuccessfully that they should decide on closing down and opening up measures in view of the disproportionate impact the state-wide lockdown would have on remote regions and local authorities where there was little or no likelihood of infections. The claim is thus that the state government did not exploit the vastness of the country to impose differentiated measures.

Where local policy space existed, conflicts between cities and states also occurred. The same partisan politics characterising federal-state relations played out in battles between Republican governors and Democratic mayors and vice versa. But even within the same party, the public spat between the Democratic governor and mayor of New York state and New York City, respectively, had catastrophic consequences for inhabitants.

Given the important role that local governments played at grass-roots level, they became part of federal and/or state plans. Funds flowed from the federal purse directly to local authorities, strengthening (or even creating) the link between these two levels.

\subsubsection{Substance of engagement}

As noted, in most instances the primary task of local governments remained the delivery of basic municipal services: water, sanitation, electricity, refuse removal, and burials, all crucial for the health and well-being of communities. In those federations where local authorities also provided secondary or primary health care, they were a vital cog of the health machinery. For example, Argentinian municipalities own 15 per cent of health institutions; many German local authorities run local hospitals; and in the US, it was mainly cities and counties that were responsible for public hospitals.

Where the federal government or states were the primary responders to the pandemic, local authorities played a supportive role and generally did so enthusiastically. They were also allocated new tasks that included testing, contact tracing, quarantining, public education, food distribution, and enforcement of restrictions. Some municipalities saw it fit to impose stricter lockdown measures than their states (Brazil, Argentina). However, municipal border closures in these two countries were quickly slapped down by federal governments using the courts. In South Africa, a municipal attempt to impose compulsory quarantining at municipal facilities was stopped in its tracks by the national government.

Local authorities, as noted, played an important role in assisting the vulnerable in their communities who fell through the national or state social welfare nets. Often, at their own discretion and due to their proximity to residents, they were able to identify and assist the most vulnerable by ways of food kitchens and shelters for the homeless; within their means, some could provide financial 
assistance too. In South Africa, for example, some municipalities gave property owners a tax holiday. Some large cities developed new online governance modalities. Moscow City managed the first lockdown in an innovative way and served as an example that other cities could emulate. This included developing an app for tracing purposes and using information technology to manage metropolitan services.

Given the large number of local authorities in any given country, their voice is usually heard at the federal and state level through organised local government, bodies which can also facilitate cooperation and mutual assistance among local authorities. During the pandemic, organised local government was largely muted, though. In Canada and South Africa, it played some lobbying roles, while in Mexico, organised along political party lines, it performed a similar function. Metropolitan governments most often dealt directly with the federal and/or state governments.

The problem of uneven capability among local authorities was also reported. The lack of capacity was, of course, exacerbated by corruption, which was in turn fuelled by the special funds that federal and state governments made available for Covid-19-related measures.

\subsubsection{Intergovernmental relations}

In Chapter 20, Saunders sets out the essential elements of, and insights into, IGR during the pandemic in 2020, and considers how well or badly this important federal element impacted on the battle against Covid-19. For the sake of the completeness of this conclusion, and for the purpose of my argument advanced below, I raise a few key issues from this chapter.

First, Saunders highlights several specific purposes that IGR served: coordination that allows some discretion at subnational levels; establishing frameworks in terms of which such coordination could take place; the sharing of resources, including revenue raised nationally; and problem-solving. Not all federations pursued all or even some of these goals, much to the detriment of providing effective governance.

Secondly, the IGR modalities in terms of which the goals were pursued were the usual structures, mechanism, and processes found in federal systems. The legislatures at the different levels of governments could play an important role during the pandemic in regard to achieving some level of coordination between the different governments' mandates; federal legislation that provided an umbrella structure for this purpose was useful. The absence of legislative coordination, which left uncertainty about who does what in a situation where speedy and decisive action is required, had profoundly negative consequences in a number of countries. As anti-Covid-19 action became the business mainly of executives, inter-jurisdictional forums stood to be crucial for coordinated action; the cases showed, however, that in some countries which had no pre-existing structures, none developed. Also, where such structures were weak, they remained so or 
were not used at all. But there were also examples of neglected or new structures coming to life out of pandemic necessity. An integral part of effective IGR is reducing intergovernmental engagements to agreements. Although not the norm, in some federations they did emerge to manage detailed health-care functions, while in others they pre-dated Covid-19 as general plans for pandemic eventualities.

Finally, Saunders draws from the cases four insights that could maximize the potential of federations to deal with emergencies such as this pandemic. First, IGR should not be an overly top-down process: it needs the participation of subnational governments. Secondly, the goal of effective IGR is not necessarily uniformity, but should allow for diversity. Thirdly, all governments must be capable to perform their allocated roles effectively. Fourthly, the usual lack of transparency and accountability in IGR may have been exacerbated by the need for speedy action and less parliamentary accountability.

\subsubsection{Intergovernmental fiscal relations}

In most of the federations, the main tax sources fall under the domain of the central government, with the exceptions of Belgium, Switzerland, and the US. Generally, then, the revenue raised by subnational governments does not match their allocated responsibilities, resulting in vertical fiscal imbalance. Most thus rely on national transfers to balance the books, as subnational borrowing is also limited. Reliance on transfers varies between countries, as well as among states and local government in the same country. Countries where states are highly dependent on transfers are, by definition, the more centralised federations: Argentina, Brazil, Ethiopia, Italy, Mexico, Nigeria, Russia, South Africa, and Spain. Transfers are effected in a variety of ways. Certain tax bases are shared by percentages, VAT and GST being among the popular ones (e.g. in Argentina, Australia, Austria, India, and Nigeria); some are in terms of block grants based on formulas; and in all countries there are also conditional or tied grants.

From an economic point of view, for a number of countries the pandemic could not have come at a worse time. Italy and South Africa were formally in a recession at the beginning of 2020, while Argentina had already declared a state of emergency in December 2019 due to an economic crisis. The drop in the oil price also deeply affected revenue in Canada (Alberta), Nigeria, and Russia. Brazil was struggling to recover from a recession, the UK faced Brexit, and India's growth rate was on a downward curve. They all struggled with high indebtedness.

Lockdown measures caused the largest economic downturn some countries had experienced since World War II. The impact was severe across the federations, with unemployment and poverty increasing dramatically. The immediate consequence was a massive drop in revenue collected at every level of government. Where taxes are shared according to percentages, such as with VAT or GST, the impact was immediate in Austria, Brazil, India, and Nigeria. The dent 
in federally collected revenue also reduced transfers to states and local governments, but in a moderate and gradual way. Local government, too, collected significantly less taxes and charges than usual. Concomitantly with dwindling revenue, the expenses of fighting the pandemic soared at all levels of government. States and local governments were saddled with costly implementation responsibilities for old and new mandates. The costs to ameliorate the social and economic consequences fell mainly to the federal government's account.

The net result was that all levels of government felt the sharp edge of Covid19's 'scissor effect': while revenues dropped, expenditures increased. This effect was experienced differently both vertically and horizontally. In Canada and Russia, subnational governments, which carried the bulk of health-care responsibilities, experienced the sharpest cuts. Horizontally, due to differing levels of economic activity and compounded by variation in infection rates, some states and local authorities felt the cut more keenly than others. Moreover, existing disparities among states and local governments deepened.

The federal response to the scissor effect was both to cut or reprioritise expenditure in non-Covid-related areas and to borrow more money to cover budget deficits. Federal expenditure cuts included decreases in the regular transfers to subnational governments, such as block grants. Given the severity of the budget shortfalls, new borrowings increased the high indebtedness and vulnerability of some countries, such as Argentina, Brazil, and South Africa. Members of the EU, on the other hand, enjoyed the cushion of the EU's various support packages.

Without the ability to increase or create new taxes, states became increasingly dependent on transfers, which they received mostly as special grants earmarked for Covid-19-related expenses. Given the discretionary nature of such grants, in a few federations accusations of party-political bias in the allocations and size of such grants were made (Nigeria, Argentina). In the US, the provisioning of such grants became a political football. Whereas there was bi-partisan support in the Congress at the outset of the pandemic for relief bills, another bill gridlocked a few months later: the Republican-controlled Senate refused to pass a bill originating in the Democratic-controlled House of Representatives because, in terms of the bill, Democratic-governed states would have benefited more from the support packages given that they had closed their economies for longer periods of time.

Where regulatory control was in the jurisdiction of the federal government, some financial control measures were loosened and others tightened. The EU eased borrowing and deficit-budget restrictions on member countries. To facilitate emergency procurement, certain procurement regulations were suspended, which in some instances led to widespread corruption (e.g. South Africa) and in turn necessitated stricter controls. Special grants were often accompanied by strict control measures (e.g. Russia). The scope for subnational borrowing was slightly opened in Brazil, Russia, and Spain.

The response to Covid-19's scissor effect on subnational governments the provision of specific grants - was depicted in most country reports as the 
centralisation of power due to increased federal control of the purse strings. This was particularly notable in Austria, Italy, Russia, and Spain.

The funding crisis in subnational governments, brought painfully to the fore by Covid-19, spurred public initiatives and calls for systemic intergovernmental fiscal reforms in Argentina, Austria, Brazil, Canada, Italy, and Mexico. Given the increased fiscal imbalance and subnational dependency, discussion arose on how this imbalance could be addressed in a more structured and equitable manner.

\subsection{Findings and policy implications}

At the outset of this chapter, three questions were posed: First, how did the federal systems under review respond to the pandemic - what were the modalities of the response and their effect on centralisation or decentralisation processes? Secondly, how well (or badly) did the federal systems fare in combating the pandemic? Were these systems, with decentralised decision-making remaining at its core, resilient enough to cope with the challenge? Thirdly, could the manner in which the systems responded - the changes brought about to federal dynamics have a lasting impact?

\subsubsection{How did federal systems respond to Covid-19?}

If one sketches an overall storyline of how federal systems dealt with Covid-19 during the initial period before vaccinations commenced, the following trends come to the fore.

Given that the pandemic required quick, concerted, and effective action which called for some form of centrist approach, federal governments in the majority of cases centralised powers concerning health care and disaster management. However, expeditiousness was not always forthcoming, as most of them were unprepared for an eventuality of such unprecedented scale and ferocity. When they got their act together, it mostly entailed centralising power through declarations of public health emergencies. In Argentina, Austria, India, Nigeria, and South Africa, the centralisation trend was a continuation of pre-pandemic trends. At the other end of the spectrum, the 'con-federal' nature of the EU was criticised for its lack of centralised decision-making that could respond quickly and decisively; the EU is not empowered by the treaties to intervene directly in health matters, except in coordinating member states and public procurement.

The concentration of powers in federal executives also occurred: in many countries the overseeing legislatures were sidelined (often with the connivance of the legislatures themselves). In having a free hand, a few federal governments also used the pandemic to pursue objectives other than those to do with the pandemic. Courts, with a few exceptions, did not interfere in federal actions.

Although states took the first lockdown steps against the pandemic because they felt the threat more acutely than federal governments, in most cases, they soon became the implementers of federal strategies rather than co-planners. 
In a few countries, the main responsibility for health care continued to lie with the states, either because the federal government had no jurisdiction (the US) or because the states were exercising their emergency health powers and the federal government might not have done any better (Canada). After the initial centralisation of powers involved in imposing lockdowns, the need for differentiation in both unlocking after the first wave and re-locking due to the second wave became apparent and brought subnational governments back to centre-stage. Despite the general trend of centralisation, in a number of federations the position of states was enhanced during the pandemic (Brazil, Canada, Mexico, the UK, and even Spain), showcasing their ability to respond swiftly, proportionately, and relatively effectively to the pandemic.

Although local authorities played an important role in keeping communities going by providing basic municipal services, they did not, on the whole, assume a major autonomous role in fighting Covid-19, bar a few exceptions (the US, Brazil). Moreover, they did not become part of a whole-of-government decision-making network. The exclusion of local government from Australia's new 'National Cabinet', which brought the states and territories together with the federal government, serves as an example.

The trend of centralising decision-making was further consolidated by the intergovernmental fiscal system. The position of federal governments, which by and large already control the major sources of tax revenue, was strengthened by the pandemic. States and local government, feeling the scissors effect of increased responsibilities and reduced revenue, became more dependent than before on fiscal transfers. Although federal financial support was forthcoming, it did little to address inequality in services delivery; where inequality existed before the onslaught of Covid-19, it deepened.

\subsubsection{How well (or badly) did the federal government respond?}

In the case studies, contributors mounted critiques of how, in their countries, the federal system failed in practice, whether in small or large part, as an effective governance system in combating the pandemic. Although some critiqued the emergency health policy, the focus of the critiques was not on federalism as a system but on how in practice it operated sub-optimally in a range of areas and resulted in high infection and death rates. For example, poor coordination and cooperation (the antithesis of healthy federalism) may have led to higher mortality rates. Equally lethal is the disproportionate impact of measures that caused social and economic harm which could have been avoided. As noted at the beginning of this chapter, the factors for a healthy federal body, as identified by Watts (2011), are democracy, non-centralism, open bargaining, and the rule of law. These factors also give content to what Michael Burgess (2012) refers to as the 'federal spirit'.

Did the case studies validate the importance of federal 'success factors' even during a health and economic crisis? Put differently, did the absence of 
any of these result in poor governance outcomes, including high death rates? Contributors point out a number of features that inhibited effective governance, including unclear division of powers; lack of coordination and cooperation; uneven capability; dominance of party-political interests; and corruption. These problems usually pre-dated the advent of Covid-19: to use the Covid-19 health terminology, their presence, I argue, constitutes 'federal co-morbidities'. Like their human equivalents, they are conditions of the federal body politic that make it prone to ill-health and less than resilient enough to contain and overcome the pandemic. These might not necessarily be single-cause explanations of failure; as the name suggests, co-morbidities are factors that, collectively and/or in conjunction with other factors, could prove fatal for a federal system to provide effective governance during a pandemic.

\subsubsection{Democracy}

First, to what extent did democratic rule continue, and did it matter? In most countries, federal, state, or local elections scheduled for 2020 were held, as happened in Brazil, Germany, Italy, Spain, and the US; in addition, referenda were held in Russia and Switzerland (after an initial suspension). The only exception is the Ethiopian federal government's decision to postpone the August 2020 federal and regional elections to 2021 . Holding elections was certainly possible in a country with the lowest infection rate of all the federations surveyed, but it was not expedient for the ruling party; the postponement set a chain of events in motion that degenerated into a civil war in the Tigray region. More complex is the impact of the more authoritarian regimes which, by definition, have highly concentrated and centralised powers, as many factors come into play: Russia seems to have coped well, counterintuitively by delegating powers to constituent units rather than appropriating them; Argentina's poor Covid performance is but a continuation of its record of poor governance; as for India, the link remains unclear; as is the case with Ethiopia and Nigeria where data are lacking.

In most countries, the legislatures, the prime institution of democracy, came under strain through the concentration of power in the executive; although legislatures were initially suspended and then came back virtually, they did not excel in their constitutional role of oversight, which in any event was weak in a number of federations. The lack of scrutiny of the executive's health policy, its choice between lives and livelihoods, as well as the disproportionate impact of some measures, was a general failure in democracies the world over. In federal systems it applied also at subnational levels. Poor oversight also facilitated the misappropriation of funds allocated for anti-Covid measures.

\subsubsection{Non-centralism}

The principle of non-centralism, which entails that a polity is underpinned by multiple centres of decision-making by democratically elected bodies, was placed 
under pressure by the need for centrally led decision-making. In the majority of federations, the principle was attenuated through centralisation. However, there are important exceptions that confirm the value of non-centralism. In the US, Mexico, and Brazil, states performed a vital federal function by acting as checks and balances on federal governments whose presidents had gone on unscientific frolics of their own. As reported, Covid-19 related deaths in the US are likely to have been higher if the response was left solely in the hands of the Trump administration, unchallenged by states.

In the same vein, centralisation through the application of uniform lockdown rules often had a disproportionate social and economic impact on a landscape of varied infection rates. This led to the calling for, and in some countries, the return of, differentiated decision-making at subnational level.

\subsubsection{Open bargaining as a dominant means of reaching decisions}

Open bargaining as the dominant means of reaching decisions entails negotiations and the give-and-take of compromises. The success stories among the federations in terms of low death rates are those where federal governments and states enjoyed close working relations: Australia, Canada, and Germany. At the other end of the spectrum, the absence of cooperation and coordination is directly linked to high mortality rates, as contributors argue in respect of Argentina, Brazil, Mexico, and the US.

Causes of this form of co-morbidity include a lack of institutions and processes that facilitate bargaining. Where no intergovernmental forums or processes existed before the pandemic, no new ones emerged. Also, weak institutions did not gain in strength during this crucial time but were eclipsed by ad hoc central bodies. Bargaining to reach common decisions was also stymied by divisive partisan politics in a few federations.

\subsubsection{The rule of law}

The definition of constitutionalism usually includes the element of rule of law, the other two being democracy and limited government. The rule of law, in turn, covers a number of elements (Bedner 2010), three of which were highlighted in the case studies: rules must exist in the first place; they must be clear; and they must be enforced. The absence of these elements indicates a serious co-morbidity.

The first element - rule by laws rather than unbridled discretion - may be superficially present in Argentina, Ethiopia, and Nigeria, but is belied by the way that heads of government used their wide discretion for the purpose of distributing resources in a partisan manner instead of on the basis of need. It fuelled subnational resentment of the federal government and undermined the trust necessary for effective coordination and cooperation. 
The second element is that rules should be clear so as to guide the conduct of governments. In particular, a lack of clarity about 'who does what' led to service and governance gaps detrimental to citizens, as occurred, for example, in Italy and Switzerland. Although not feasible to provide for watertight allocations of powers, uncertainty in the vital areas of health care had devastating consequences.

The third element, enforcement of the rules, was conspicuous by its absence in countries with high levels of corruption. Because procurement during the pandemic required expedited procedures, corruption flourished in countries where lawlessness is woven into the weft of governance.

\subsubsection{Capability to govern}

One 'success factor' underlying effective federal systems is so self-evident that it is hardly mentioned in the literature, namely that each government, bestowed with a set of responsibilities, is capable of discharging them efficiently and effectively. Several contributors point out the obvious adverse consequences of a lack of sufficient capability, whether at federal, state, or local level. In view of the pandemic, health care and other functions were centralised on the assumption that federal governments would be able to do a better, more coordinated job of carrying them out than states; likewise, functions are devolved to subnational governments on the assumption that they were capable of discharging them more effectively than federal governments. Where either of these assumptions proves to be groundless, a federal co-morbidity is evident. Where federal governments centralised subnational health functions, some of them had no pre-existing capacity in that field, with examples coming from Italy and Switzerland. In certain countries, capacity was unevenly spread among subnational governments. In Italy, some of the southern regions lacked the wherewithal to take the necessary curative and preventative measures; the same was true of some South African provinces.

In conclusion, the contributors identified federal co-morbidities in all the countries under review, with these co-morbidities having negative consequences in practice. The number, nature, and severity of the co-morbidities, however, varied considerably among the federations. It was beyond the scope of this study to measure the pathogenicity of each of them individually or collectively in terms of infection or death rates. The explanatory value that the presence or absence of federal co-morbidities carries for the trends in infection and death rates during the first 10 months of 2020 (see Introduction, Table 0.1), must thus be treated with great caution. Indeed, more research is needed for determining, inter alia, the accuracy of reported figures and the extent to which comparisons are meaningful; the weight and combination of co-morbidities; the role of geospatial, demographic (including age profiles), economic, political and governance factors; and, above all, the nature of the relevant health policies.

The aim here is to identify federal co-morbidities that may be hindering the response to the pandemic. It is clear that if federal co-morbidities are accurately 
highlighted, corrective action, where possible, can be taken during the course of the Covid-19 pandemic - at the time of this writing still ongoing and in some countries mutating into a third and even fourth wave of infection - and steps can also taken to put preventative measures in place for contending with future health and other emergencies.

\subsubsection{Future changes?}

The last question is whether changes that occurred in federal dynamics due to Covid-19 are likely to be long-lasting. Did the pandemic provide a 'policy window' for fundamental changes further down the road? The contributors are rightly hesitant to predict changes with any degree of certainty, and any predictions remain speculative. The following can be noted, though.

In the majority of cases, no dramatic changes are predicted. Federations that were on a centralisation trajectory are likely to continue on it. In a number of them, however, changes towards greater decentralisation are a possibility: these are Brazil, Mexico, Russia, Spain, and the UK, in each case for different reasons. Because federal policy is so imbedded in the partisan politics of Mexico, changes in the current party political alignment may result in pro-federalists coming to the fore. In Brazil, the denialist President confirmed the importance of the states in times of crisis. The devolved units of the UK have increased their profile as competent governments enjoying higher trust than the central government and may even be the catalyst that pushes Scotland towards independence. In Russiaironically, given the centralist trend and party dominance - the successful devolution of powers to constituent units has bolstered their image as well. In Spain, the emergence of 'co-governance' may give Autonomous Communities a new spring in their step and bring the Catalan question back on the table.

More modestly, the strongest calls for change have been in the field of intergovernmental fiscal relations, which during the pandemic produced greater dependence and inequity. Calls in Argentina, Brazil, Germany, Mexico, South Africa, and Spain may result in changes to reduce subnational dependency on federal transfers and at the same time ensure greater equalisation.

\subsection{Concluding remarks}

As the pandemic is still ongoing at the time of writing (March 2021) and the dynamics of vaccination are still to be played out, Covid-19's full impact on the federal systems under review is still to be assessed. Once the health aspects are under control, the social and economic consequences will continue to reverberate through the next few years. What this volume provides is a first-cut analysis of the crucial first ten months of 2020 when the shock to the federal systems was at its severest and federal co-morbidities were painfully revealed. Without attempting to explain the variations in infection and death rates, a framework of analysing the role that federal governance played is suggested. Further research is 
called for on both the initial government actions as well as the continuing battle against Covid-19. It is hoped that this volume may provide a baseline study in this endeavour. In the meanwhile, the study may provide valuable lessons on remedying federal co-morbidities and preparing for the next calamity.

\section{Note}

1 I wish to thank the contributors of the respective chapters for their corrections, comments, and suggestions on this chapter which improved the text considerably.

\section{References}

Aroney, Nicholas and John Kincaid. 2017. 'Comparative Observations and Conclusions', in Nicholas Aroney and John Kincaid (eds), Courts in Federal Countries: Federalists or Unitarists?, pp. 482-540. Toronto: University of Toronto Press.

Bedner, Adriaan. 2010. 'An Elementary Approach to the Rule of Law', Hague Journal on the Rule of Law, 2: 48-74.

Béland, D. et al. 2021. 'Covid-19, Federalism, and Health Care Financing in Canada, the United States, and Mexico', Journal of Comparative Policy Analysis: Research and Practice, 13: $1-14$.

Burgess, Michael. 2012. In Search of the Federal Spirit: New Theoretical and Empirical Perspectives in Comparative Federalism. Oxford: Oxford University Press.

Detterbeck, Klaus and Eva Hepburn. 2010. 'Party Politics in Multi-Level Systems: Party Responses to New Challenges in European Democracies', in Jan Erk and Wilfried Swenden (eds), New Directions in Federalism Studies, pp. 106-125. Abingdon: Routledge.

Poirier, Johanne and Cheryl Saunders. 2015. 'Conclusion: Comparative Experience of Intergovernmental Relations in Federal Systems', in Johanne Poirier, Cheryl Saunders and John Kincaid (eds), Intergovernmental Relations in Federal Systems, pp. 440-495. Don Mills ONT: Oxford University Press.

Steytler, Nico. 2017. 'Concurrency of Powers: The Zebra in the Room', in Nico Steytler (ed.), Concurrent Powers in Federal Systems: Meaning, Making, Managing, pp. 300-350. The Hague: Brill/Nijhoff.

Transparency International. 2020. Corruption Perception Index 2020.

Vrushi, Jon and Roberto Martínez B. Kubutschka. 2020. 'Why Fighting Corruption Matters in Times of Covid-19', Transparency International, https://www.transparency.org/ en/news/cpi-2020-research-analysis-why-fighting-corruption-matters-in-times-ofcovid-19 (accessed on 8 February 2020).

Watts, Ronald L. 2011. 'The Federal Idea and its Contemporary Relevance', in Thomas J. Courchene, John R. Allen, Christian Leuprecht and Nadia Verrelli (eds), The Federal Idea: Essays in Honour of Ronald L. Watts, pp. 13-27. Montreal and Kingston: McGill-Queen's University Press.

World Bank. 2020. World Bank Country and Lending Groups, https://datahelpdesk. worldbank.org/knowledgebase/articles/906519-world-bank-country-and-lendinggroups (accessed on 20 February 2021). 